$\xi=-1$

\title{
Potential of Regulation of Slum Area in The Village Meranti Pandak Pekanbaru City
}

\author{
LD Putri ${ }^{1 *}$, Harsini $^{1}$, SR Nasution ${ }^{1}$ \\ ${ }^{1}$ Universitas Lancang Kuning \\ *E-mail:lusidwiputri@unilak.ac.id \\ This Paper is based on a presentation given by the authors at "Workshop of KO2PI" held from 19 January 2018 to 20 January 2018 in \\ Indonesia.
}

\begin{abstract}
The slum area of Meranti Pandak is one of seven slum areas in Pekanbaru City according to Mayor's Decree No. 151/2016, is on the edge of the vulnerable Siak River with overflow due to ups and downs. This study aims to produce a draft slum area design direction as one of the references for related parties to create Pekanbaru free from slum. The research method used is quantitative research method using secondary data as well as primary data with data collection techniques through observation and filling questionnaire . Result of requirement analysis of structuring slums are the three aspects structuring approach settlement infrastructure; improvements to environmental road accessibility, drinking water services, sanitation access fulfillment, wastewater management and waste management and fire hazard security, enhanced oversight of the development of settlement development from internal parties; LKM, TIPP, POKJA and internal resource team as well as from external parties; college, consult's, government and private sectors as well as community empowerment methods; counseling, mentoring and technical assistance.
\end{abstract}

Keywords: development of utilities, infrastructure, meranti pandak, settlement, slum areas.

\section{Introduction}

Based on the National Long-Term Development Plan (RPJPN) 2005-2025; realizing a city without slums and Medium Term Development Plan (RPJMN) 2015-2019; slum zero targets as well as driven by the mandate of the Law on housing and residential areas is necessary to create habitable and sustainable settlements [1] . Pekanbaru City slum area covering an area of 113.56 hectares in seven (7) region with 19 (nineteen) identified urban slums by Mayor's Decree No. 151/2016, one of them is the area of Meranti Pandak which is in Meranti Pandak Rumbai Pesisir District. This slum area of Meranti is located on the outskirts of the Siak River which is always experiencing ups and downs. Meranti Pandak consists of $13 \mathrm{RW}$ and $56 \mathrm{RT}$.

Based on UU No. 1 of 2011 on Housing and Settlement Area, it is explained that Slum Settlements are uninhabitable settlements due to building irregularities, high density of buildings, and quality of buildings and facilities that do not meet the requirements, while the Housing is a housing underground degradation of function quality as shelter. Factors causing a region to become slim is caused by direct factors and indirect factors, direct factors; physical environmental factors ie housing, sanitation, household waste and road network, while indirect factors; economic factors and social culture[2]. The condition of slums can be categorized according to the slum categories of each region, such as Slum, Slough, Slough, Almost Slum and Not Slum [3]

Various problems faced by the community of Meranti Pandak. The arrangement of the area is only focused on the southern Siak River (direction to the center of the city), while the area around the banks of the North Siak River is still much to be addressed. This condition is worsened by the lives of people who mostly middle to lower. The unfavorable environmental sector is supported by the difficult economic life and the inadequate institutional function that exists in the community increasingly makes the slum area of Meranti Pandak lagging behind other areas. The limited resources possessed by the community requires the participation of universities through various forms of activities called collaboration as well as the realization of the implementation of Tri Dharma Perguruan Tinggi [4]

\section{Literature Review}

The area of Kumuh Meranti includes a high priority (very heavy) slum area located on the outskirts of Siak River, Pekanbaru City. Identify the characteristics of the slums [5] resulted in the fact that in slum settlements there is a tendency that the worse the category of slum, the worse is the condition in terms of the provision of facilities and infrastructure, the level of education, the level of income and also the hazard to the banjo/ puddle. According to [6] identification of slum areas in riparian areas include criteria of economic vitality, non-economic vitality (the feasibility of the area as a settlement), land status, physical condition of the building, condition of infrastructure and facilities; roads, drainage, fresh water, wastewater, local government commitments and priority handling.There is a marked difference in the slum level between the coastal and non-coastal areas where the coastal area on average has a much higher slum rate than noncoastal areas where significantly increasing slum levels are population density, poverty level, land legality and clean water services as well as open space, as for educational level factors, security vulnerability, road conditions, and average household members have no effect on the slum level [7]. 
The environmental characteristics of slum settlements [8] results in the fact that if slum conditions are not controlled for growth, environmental quality and public health will continue to decline, people's habits also have a major effect as the habit of disposing of garbage, dirty water and latrines in rivers makes the river polluted, awareness of the population on environmental health so that it implies the quality of the environment that is prone to flood and quality of life of the people who are vulnerable to epidemic of a disease. According to [9] in addition to infrastructure development is also carried out strengthening the capacity of the community in terms of economic, socio-cultural and vocational training and socialization for capacity building. Potentials biased in slums are improved drainage, clean water and waste water management and waste management [10].

\section{Methodology}

The research method used is quantitative research method using secondary data as well as primary data with data collection techniques through observation and filling out questionnaires. Secondary data is obtained from the Offender of the Sloppy City Program which is a program of Directorate General of Human Settlements Ministry of Public Works and People's Housing in the form of baseline data of Urban Village in 2016 which then verified and clarified again by doing field observation with the aim to update the data. Primary data collection is done by direct observation method of spaciousness and filling the questionnaire. This data is then summarized and analyzed to become one formula.

\section{Result and discussion}

\subsection{Potential for settlement infrastructure development}

Potential for infrastructure development Meranti Pandak slums which become priority can be seen table 1 as the result of secondary data analysis and primary data and observation in the field.

Table 1. Potential Developing Infrastructure at Meranti Pandak

\begin{tabular}{l|c|l}
\hline \multicolumn{1}{c|}{ Criteria } & $\%$ & \multicolumn{1}{c}{ Parameter } \\
\hline Access road environment 47 & $\begin{array}{l}\text { The condition of the road network in the } \\
\text { residential area has a minimum quality is } \\
\text { adequate }\end{array}$ \\
Drinking water services $\quad 52$ & $\begin{array}{l}\text { Communities served by drinking water, } \\
\text { bathing and laundry facilities (proper } \\
\text { piped or non-piped protected) }\end{array}$ \\
Access to sanitation & $30 \begin{array}{l}\text { Residential buildings that do not have } \\
\text { access to latrines }\end{array}$ \\
Waste water management $49 \begin{array}{l}\text { Separate sewerage pipes with environmen- } \\
\text { tal drainage channels }\end{array}$ \\
Waste management \\
$43 \begin{array}{l}\text { Domestic household waste in residential } \\
\text { areas is transported to TPS / TPA 2 times a } \\
\text { week }\end{array}$ \\
Security of fire hazards & $11 \begin{array}{l}\text { The residential area has fire protection } \\
\text { facilities }\end{array}$ \\
\hline
\end{tabular}

\subsubsection{Environmental road access}

Based on the above data can be seen $53 \%$ of the condition of the road network or the planning area in bad conditions, means must be done rejuvenation or redevelopment of the road conditions. This is because of the main function of the road as the main access out and mobility of community activities in the planning area.

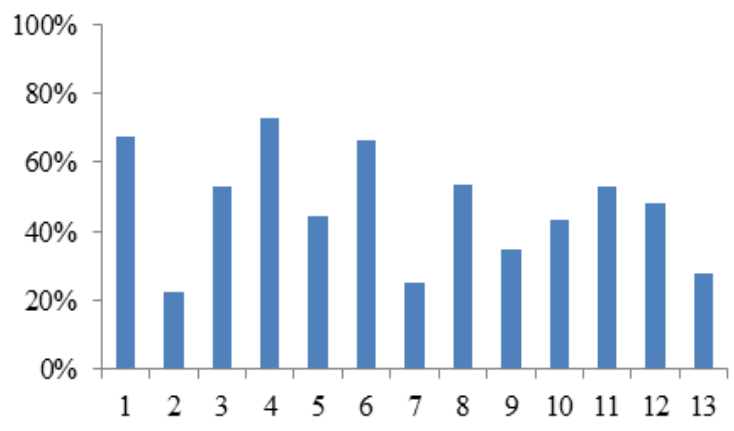

Fig. 1: Environmental road access

\subsubsection{Drinking water services}

Based on the conditions above $48 \%$ of residential buildings are not served by the system of clean water / piping network. For that, it needs serious handling, especially by building clean water installations that adequately adjust to the condition of the area so that water supply can be fulfilled in the planning area.

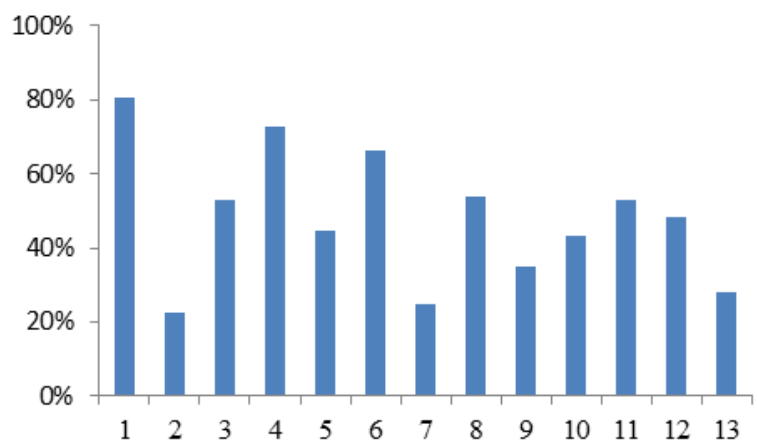

Fig. 2: Drinking water services

\subsubsection{Sanitation access}

Based on the above data can be seen for the location of settlements that do not have access to latrines as much as $30 \%$. Of course, good handling is necessary for the construction of latrines in accordance with technical and other policies that can assist in overcoming the problem.

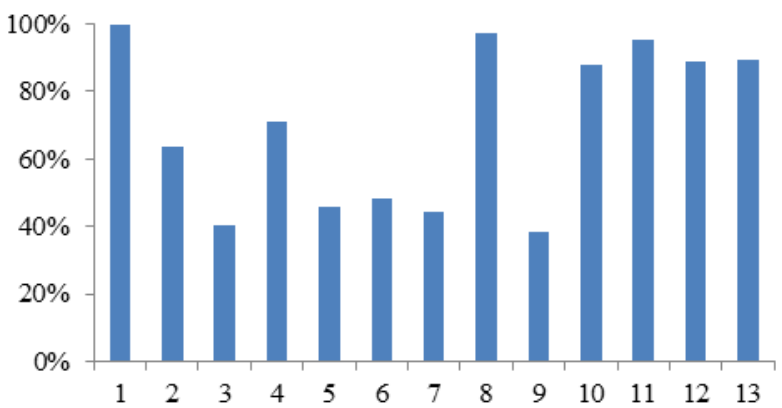

Fig. 3: Sanitation access

\subsubsection{Wastewater management}

Based on the above data can be seen for the location of the settlement of the wastewater management system $51 \%$ disposal directly drainage environment. This is certainly a problem, especially for environmental problems. 


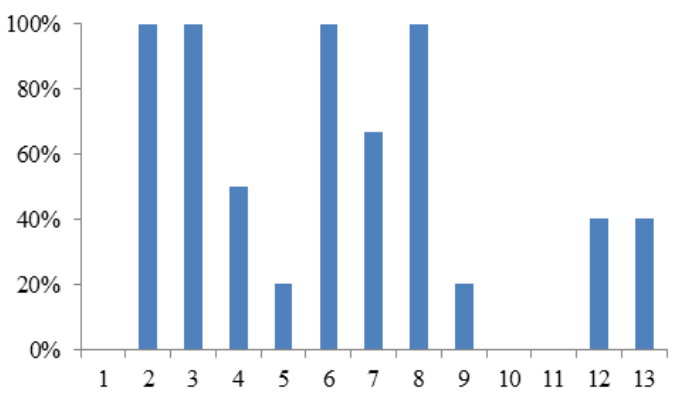

Fig. 4: Wastewater management

\subsubsection{Waste management}

Based on data above $57 \%$ of households served by the good waste management system in the planning area. While $43 \%$ of households are not served. Therefore, an integrated waste management system that is managed by the community must be built or for the transportation will be carried out by the government.

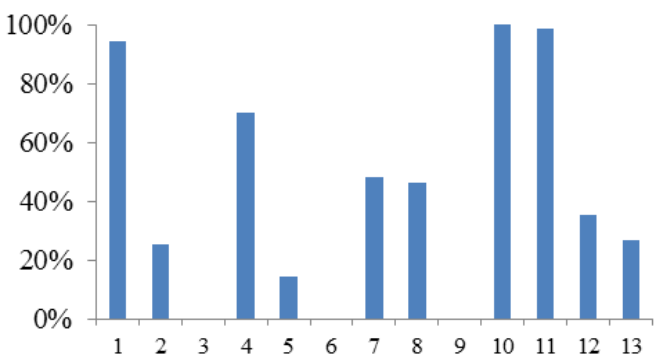

Fig. 5: Waste management

\subsubsection{Fire hazards security}

Based on the above data can be seen that the planning area there are $11 \%$ facilities and infrastructure fire protection. This is very worrying because the area has a dense residential level. Based on these conditions, efforts should be made in accordance with the technical standards of security. Both from the effort to make the evacuation path and the provision of a hydrant at the location points that are prone to fire disaster.

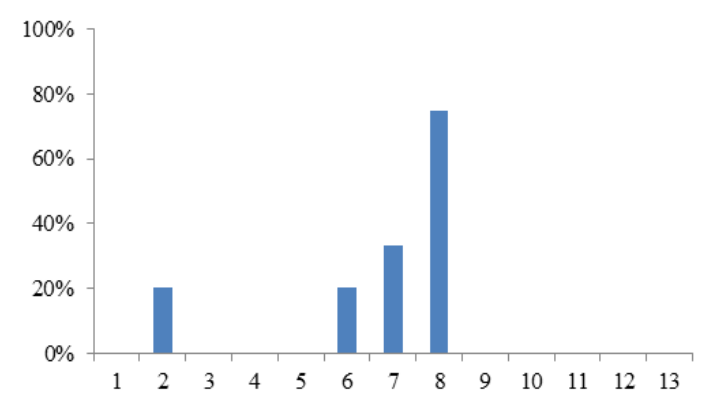

Fig. 6: Fire hazards security

\subsection{Potential analysis of settlement infrastruc- ture development}

The potential for the development of settlement infrastructure is the most important part of the arrangement of slum areas in Meranti Pandak Village. Potential development of utilities are as follows:

\subsubsection{Potential of environmental road access development}

The scenario of handling the problems in meeting the needs of environmental accessibility is in the following way :

a. Conduct development stages in the planning area by prioritizing priority areas first. Which means development will be done in the first year.

b. Furthermore, to reach $0 \%$ by 2019 , priority development activities of development accessibility will be prepared by looking at the percentage of development in 2018 and completing the development shortfall in the next year.

c. In the area of environmental quality improvement planning, accessibility will be done with the pattern of rejuvenation by restoring the main function of the road to its original function.

\subsubsection{Potential for development of water / raw service}

The scenario the handling problems in meeting the water service can be described as follows:

a. Increasing the supply of production facilities and optimizing existing production facilities.

b. Development of piping systems for the region.

c. Development of the application of appropriate technology.

d. Increased self-reliance of village communities in the provision and management of clean water.

e. Increased extension on the importance of clean water for public health

\subsubsection{Potential development of wastewater service}

The scenario of handling problems in fulfilling sanitation services (wastewater) can be explained as follows, as well as the clean water network system, the wastewater network system to be developed in the planning area will also apply local treatment system within each block or sub-block and not allowed to be discharged directly to rivers / creeks except domestic wastewater in the category of gray water.

Thus, like a clean water network, the sewerage pipes in the planning area will be placed pipe with a suitable diameter for both primary and secondary pipes. Placement of the pipes is also done by planting it in the soil. The location is directed to take advantage of the land area under the pedestrian path with the utilization of land as wide as $50 \mathrm{~cm}-70 \mathrm{~cm}$. Planting this pipe is done adjacent to the clean water pipe with the provision of distance from the top to the surface of the ground at least $25 \mathrm{~cm}$

\subsubsection{Potential for development of waste management}

The scenario of handling problems in fulfilling waste service can be explained as follows:

a. For places on the main roadside, waste management is used "Door to Door" system where garbage trucks pick up waste from households to be transported and disposed of to landfill.

b. For places not covered by garbage trucks, a depot system is used where garbage is collected in household trash / trash cans, then picked up by janitor by using trash pedicab to be transported and stacked at the TPS before being transported to TPA

c. Provide TPS locations in traditional market areas that are designed and managed to be transported on a daily basis.

\subsubsection{Potential development of fire hazards security services}

The scenario of handling the problems in meeting the fire hazard security can be explained as follows:

a. Prepare a hydrant or water dispenser which will be placed in thick-prone point of fire. Hydrant is functioning when fire cars are unable or not bias to reach the location of the fire located densely populated residential

b. Prepare the evacuation route in planning areas prone to fire disaster by making evacuation route map in case of fire 
c. Socialization of the community against fire hazards and prevention efforts

\subsection{Improvement plan for development of settlement devel- opment}

In the plan of improvement of development supervision of settlement, it is needed the implementing parties that play an active role here. The implementing party is divided into 2, namely;

\section{Internal Executives}

a. Community Self-Help Institution (LKM)

The role of LKM as the development of settlement development is needed to dig back the noble values of humanity and social values as the foundation of social capital (social capital) of community life.

b. Core Participatory Planning Team (TIPP)

Core Participatory Planning Team is a special team under LKM established to implement the Participatory Planning process and has the duty to carry out every stage of Participatory Planning activities, in accordance with the work plan and program implementation schedule whose members consist of volunteers as core personnel in participatory planning.

c. Working Group (POKJA)

The Core Team for Participatory Planning is supported by working groups whose members are TIPP and volunteer elements. In the village of Meranti Pandak is divided into 3 groups, namely: Working Group Environment, Pokja Economic, Social Working Group

d. Resource Team

This resource consists of volunteers and caring groups consisting of Meranti Pandak urban villagers or who are members of the LKM, TIPP, and POKJA . Resource team related to settlement area.

\section{External Executives}

a. College

Limitations of resources owned by the community require the participation of universities through various forms of activities called collaboration as well as a form of implementation of Tri Dharma Perguruan Tinggi

b. Consultant

Consultants are experts who have competence in participatory planning infrastructure of residential infrastructure to be recruited and assigned to assist and strengthen community capacity (LKM, Lurah, and TIPP) in carrying out each stage of the program .

c. Government

The government is very important here because without the government development in a region will not run properly. Therefore the need for the government as a captain who can collaborate with other agencies.

d. Private parties

Private parties such as Uniersty and other private companies are instrumental in assisting the government in funding for development in an area. Th collaboration of private parties can be done with the rules that have been determined.

\section{Community Empowerment Plan}

Community Empowerment is done through the following methods :

\section{a. Counseling}

Counseling is an activity to provide information in improving knowledge and awareness of the community related to the prevention of the growth and development of slum housing and slums.

b. Coaching

Guidance is an activity to provide guidance or explanation on how to work on activities or restrictions on certain activities related to the prevention of the growth and development of slum housing and slums.

\section{c. Technical support}

Technical support consists of physical technical assistance, directed at maintenance / repair or completion of physical components that become slum parameters, and non-physical technical assistance, directed to the preparation of software elements of arrangement and planning, including facilitation of planning arrangement; norms, standards, procedures, and criteria; strengthening institutional capacity; government cooperation with the private sector.

\section{Conclusion}

Some potential development of slum settlement infrastructure in Meranti Pandak can be described based on 3 (three) aspects;

1. Potential for settlement infrastructure development Settlement infrastructure that needs to be developed is environmental road accessibility, drinking water services ( raw ), sanitation access, wastewater management, waste management and fire hazard protection.

2. Improved monitoring of the development of settlement development from internal parties ; MFI, TIPP, POKJA and internal resource team as well as from external parties; universities, consultants, government and private parties.

3. Community empowerment by the method; counseling, mentoring and technical assistance

\section{Acknowledgement}

Acknowledgments to the Program KOTAKU of Province Riau with the MoU and MoA cooperation ground in 2016.

\section{References}

[1] UU No.1, "Undang Undang Republik Indonesia Nomor 1 Tahun 2011 tentang Perumahan dan Kawasan Permukiman," Republik Indones., p. 136, 2011

[2] A. Hariyanto, "Strategi penanganan kawasan kumuh sebagai upaya menciptakan lingkungan perumahan dan permukiman yang sehat (contoh kasus: Kota Pangkalpinang)," J. PWK Unisba, vol. 7, no. 2, pp. 11-37, 2007.

[3] A. B. Mardhanie, "Vol. V No. 1, Maret 2013," INERSIA, vol. V, no. 1 , pp. $1-8,2013$

[4] L. D. Putri, "PKMCSR_2016_Kolaborasi." KONFERENSI NASIONAL PKM DAN CSR KE 2 - 2016, Padang, 2016.

[5] N. Fitria and R. P. Setiawan, "Identifikasi Karakteristik Lingkungan Permukiman Kumuh di Kelurahan Kapuk , Jakarta Barat," J. Tek. Pomits, vol. 3, no. 2, 2014.

[6] J. D. Putro, "Penataan kawasan kumuh pinggiran sungai di kecamatan sungai raya," Tek. Sipil Untan, vol. 11, no. no 1, pp. 19-34, 2011.

[7] N. Siti, M. T. B. S. Jaya, and S. Bakri, "Faktor-faktor yang menyebabkan permukiman kumuh di kota bandar lampung," vol. 2, no. 1, pp. 25-39, 2015.

[8] N. Amri, "Karakteristik Lingkungan Permukiman Kumuh Tepian Sungai Kecamatan Kolaka, Sulawesi Tenggara," Univ. Hasanuddin, no. 1927, 2009.

[9] U. Eka Dahlan, "Strategi Dan Tantangan Penanganan Kawasan Kumuh Di Kota Ambon," J. Fikratuna, vol. 8, no. 2, pp. 127144, 2016

[10] L. D. Putri, "Potensi Pengembangan Utilitas Wilayah Kumuh Di Kelurahan Muara Fajar Kota Pekanbaru," J. Tek. Sipil Unaya, vol. 4, no. 1, pp. 11-20, 2018. 